\title{
DISCORDANT AGES RELATED TO RESERVOIR EFFECT OF ASSOCIATED ARCHAEOLOGIC REMAINS FROM THE TUNEL SITE, BEAGLE CHANNEL, ARGENTINE REPUBLIC**
}

\author{
MIGUEL C ALBERO, FERNANDO E ANGIOLINI
}

Instituto de Geocronología y Geología Isotópica (INGEIS), Pabellón INGEIS, Ciudad Universitaria, 1428 Buenos Aires, Argentina

and

\section{ERNESTO L PIANA}

Centro Austral de Investigaciones Científicas (CADIC)

Casilla de Correo 92, 9410 Ushuaia, Argentina

ABSTRACT. Evidence of a tradition of human maritime adaptation was recovered from various sites at Beagle Channel dating back to ca $6000 \mathrm{yr}$ BP. Final occupations date to European settlement in the 19 th century. The Túnel site exhibits discontinuous human occupation ranging from 6000 to $500 \mathrm{yr} \mathrm{BP}$, represented by different archaeologic remains in each layer. Associated charcoal, mollusk shells, and Lama guanicoe and Arctocephalus australis bones were dated. Shells and Arctocephalus are consistently older than charcoal, demonstrating the reservoir effect at Beagle Channel. Results encourage further work in the area to evaluate the spatial and temporal magnitude of the effect.

\section{INTRODUCTION}

It is well known that marine organisms show a depleted ${ }^{14} \mathrm{C} /{ }^{12} \mathrm{C}$ ratio in comparison to air and terrestrial organisms. This depletion causes ${ }^{14} \mathrm{C}$ dates of marine shells to be some hundreds of years greater than real ages, since their ${ }^{14} \mathrm{C}$ content depends on the isotope content of the water masses in which the dated organisms lived.

The magnitude of this depletion (reservoir effect), which is a function of geographic location, cannot be easily measured because confirmed contemporaneus marine and continental samples are required.

Several authors have reported ${ }^{14} \mathrm{C}$ dates of modern pre-bomb shells, eg, (Mangerud \& Gulliksen, 1975; Taylor \& Berger, 1967; Berger, Taylor \& Libby, 1966); others reported pairs of shell/charcoal or shell/wood ${ }^{14} \mathrm{C}$ ages (Hubbs, Bien \& Suess, 1965; Dyck \& Fyles, 1962; Hubbs, Bien \& Suess, 1960; Ferguson \& Libby, 1963; Olsson \& Broecker, 1959). The reservoir effect, using marine mammals, was also studied by Olsson (1980). The relationship between reservoir effect and oceanic circulation patterns was discussed in some of these papers.

Ignorance of the magnitude of the reservoir effect might lead to serious errors (especially in archaeologic studies) if marine samples associated with settlement sites are dated to establish anthropologic chronologies. Further, depletion of ${ }^{14} \mathrm{C}$ in dissolved carbon might be changed as a result of changes in oceanic circulation patterns, eg, by mixing of shallow with deeper and older sea waters. Thus, a spatial and temporal calibration of this effect is desirable if ${ }^{14} \mathrm{C}$ ages on marine materials are to be reliable.

Two simultaneous conditions are required for the possible evaluation

* Contribution no. 90 of INGEIS 
of the reservoir effect:

1) Coexistence of organic materials from terrestrial and marine sources-age comparisons between terrestrial samples of known age and marine samples would give the magnitude of the effect.

2) Certainty of contemporaneity of the samples - this can be obtained if the dated samples are short-lived materials (sensu Säve-Söderbergh, 1970 ) and if the collection procedure of the samples allows for an accurate determination of very short depositional periods.

Both conditions were found at the Túnel site, on the north shore of Beagle Channel, Isla Grande de Tierra del Fuego (54 49' 15" S; $68^{\circ} 09^{\prime} 44^{\prime \prime}$ W) (Fig 1). Archaeologic excavations were made since 1976 at this site in search of aboriginal occupation floors representing a marine littoral adaptation since ca $6000 \mathrm{yr}$ BP.

The climate is very cold and rainy and shows a dense Nothofagus sp forest during the period of occupation. Seven occupations were identified; 6 were ${ }^{14} \mathrm{C}$ dated. The second component shows a discontinuous occupation for ca $200 \mathrm{yr}$ at ca $6000 \mathrm{yr}$ BP. More than 100 short episodes were identified
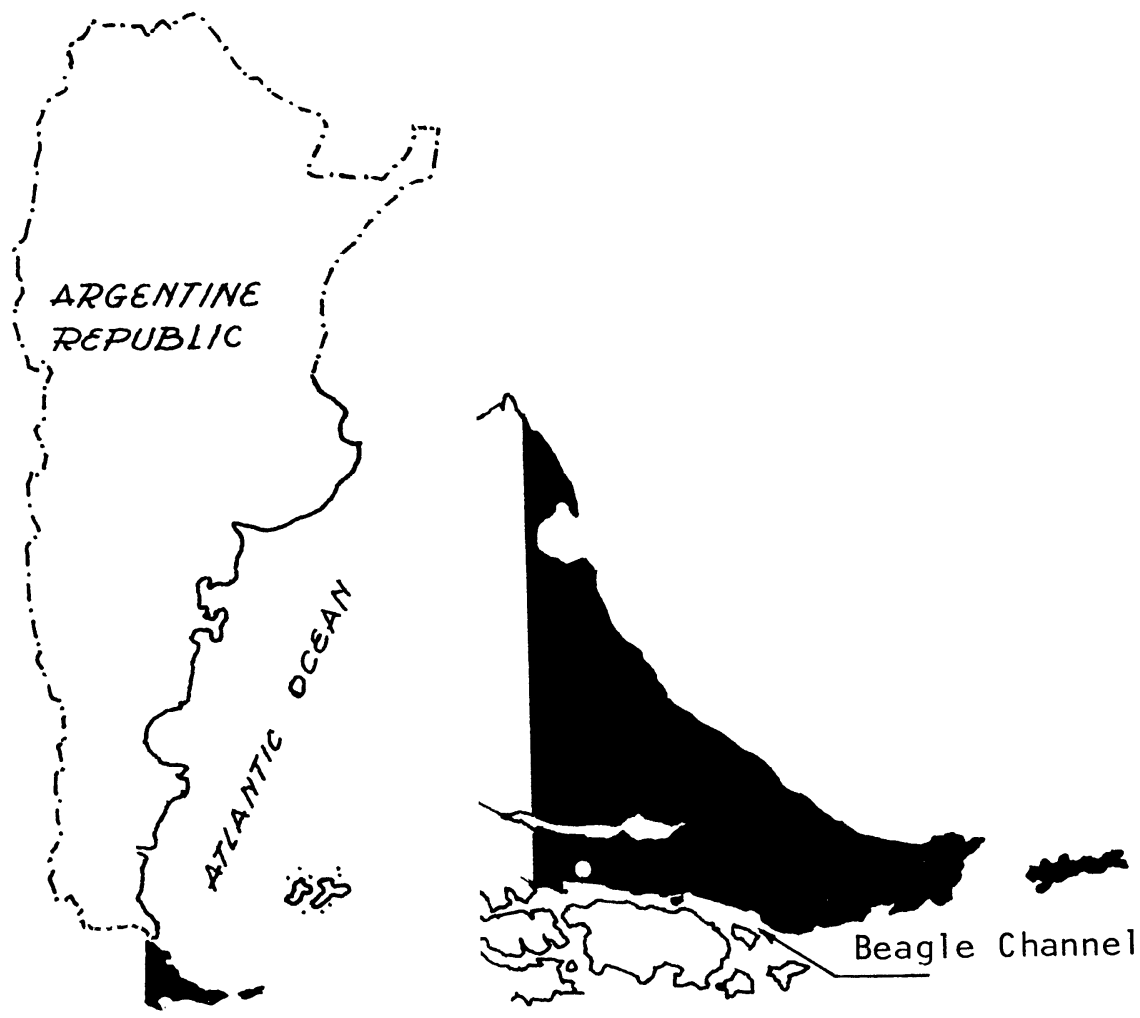

Fig 1. Location of the Túnel site (white dot) at the northern shore of Beagle Channel (Tierra del Fuego Island) 
during this period. Later occupations are dated ca 4250, 2920, 2690, 1910 and $450 \mathrm{yr}$ BP.

Archaeologic data reveal a sea canoe nomadic system with an economy based on sea lion (Arctocephalus australis) and shore birds (Phalocrocorax sp and Spheniscus sp) and the consumption of huge quantities of mussels. Continental resources such as guanaco (Lama guanicoe) were used as diet complement.

\section{METHODOLOGY AND RESULTS}

Excavation techniques developed for shell-midden sites like Túnel aid in distinguishing short-term shell accumulation based on size, fragmentation, color, packing and compression of the shells, matrix color, and composition and discordance of surfaces. These plus quantity of shells and size of post holes enable us to conclude that each of these assemblages were developed in hardly more than a few days, which ensures a very reliable contemporaneity among these shells, bones, and charcoal.

We chose Level D7, Trench IV, corresponding to the second component (Orquera \& Piana, 1983) with a wide variety of ${ }^{14} \mathrm{C}$ datable materials, for analysis. We used liquid scintillation counting of synthesized benzene (Albero \& Angiolini, 1983). Pretreatment of shells comprised hot $\mathrm{H}_{2} \mathrm{O}_{2}$ treatment plus $2 \% \mathrm{HCl}$ outer layer removal (ca $15 \%$ loss in weight). Despite the negligible humus content of the midden, charcoal was pretreated following laboratory routine, which consists of several washings with $2 \% \mathrm{HONa}$ at $100^{\circ} \mathrm{C}$ for 30 minutes until a clear extract is obtained followed by $2 \% \mathrm{HCl}$ washings $\left(\mathrm{ca} 80^{\circ} \mathrm{C}\right)$ until all carbonate is removed. This procedure has proved to yield pure samples free from contamination. Collagen was extracted from bones with the technique outlined by DeNiro and Epstein (1981). $\delta^{13} \mathrm{C}$ measurements were performed in the Stable Isotopes Laboratory of INGEIS using a double-collector mass spectrometer Micromass 602-D (Panarello et al, 1981). Errors in $\delta^{13} \mathrm{C}$ measurements are $\pm 0.3 \%$.

The dated materials, $\delta{ }^{13} \mathrm{C}$ values vs $\mathrm{PDB}$, and ${ }^{14} \mathrm{C}$ ages, normalized to $\delta^{13} \mathrm{C}=-25 \%$ are presented in Table 1 .

\section{DISCUSSION}

If we consider the charcoal age as "true" for the layer, shell ages are consistently older, the only exception being Balanus sp. The mean age for the shells is $5980 \pm 480$. If the Balanus sp age is not considered, the mean rises to 6150 and the deviation diminishes to 250. Further elimination of the Trophon sp age changes the values for the mean and standard deviation to 6260 and 70 , respectively, for the four species.

Charcoal age has been considered as a reference for the following reasons: 1) Pollen records show that Nothofagus was the only tree present in the area at that time; 2) Nothofagus lives ca $100 \mathrm{yr}$; 3) Owing to the high humidity at the the site, wood becomes unusable for fire in ca 15-20 yr. The hypothesis of an old piece of wood burned in the fire pit is rejected in this case.

Bone collagen age of sea lion (Arctocephalus australis) agrees with shell mean age, indicating that reservoir effect is also evident for marine mam- 
TABLE 1

Dated materials, $\delta^{13} \mathrm{C}$ values vs $\mathrm{PDB}$ and ${ }^{14} \mathrm{C}$ ages normalized to $\delta^{13} \mathrm{C}=-25 \%$

\begin{tabular}{|c|c|c|c|c|}
\hline Sample no. & Material & Species & $\delta^{13} \mathrm{C}(\% 0)$ & ${ }^{14} \mathrm{C}$ age (yr BP) \\
\hline AC-0683 & Charcoal & Nothofagus sp & -24.0 & $5630 \pm 120$ \\
\hline-0693 & Shell & Nacella sp & 3.4 & $6220 \pm 120$ \\
\hline-() 697 & Shell & Fisurella $\mathrm{sp}$ & 2.8 & $6340 \pm 130$ \\
\hline-0695 & Shell & Balanus sp & 3.0 & $5110 \pm 130$ \\
\hline-0694 & Shell & Mytilus sp & 2.1 & $6180 \pm 120$ \\
\hline-0696 & Shell & Aulacomyas sp & $0.0 *$ & $6290 \pm 120$ \\
\hline-0676 & Shell & Trophon sp & 4.9 & $5720 \pm 120$ \\
\hline-0703 & Bone collagen & Lama guanicoe & -20.5 & $5280 \pm 100$ \\
\hline-0698 & Bone collagen & Arctocephalus australis & -11.8 & $6220 \pm 140$ \\
\hline
\end{tabular}

* Assumed value

mals, as previously concluded by Olsson (1980). If this sample is included with marine shells, the mean age remains practically unchanged $(6250 \pm$ $65)$ and the difference between this mean and the charcoal age reflects the reservoir effect in the area, which is $620 \pm 140 \mathrm{yr}$ or $\Delta=-74 \pm 16 \%$ for $6000 \mathrm{yr}$ BP $\left(\delta^{13} \mathrm{C}\right.$ and age normalized, Stuiver \& Polach, 1977).

Even though migration patterns of sea lions are unknown previous to European hunting in the 19th century present evidence indicates that their habitat was restricted to the Beagle Channel. In this case, there is no reason to believe that the reservoir effect in the area where the sea lion lived would be different to that of the neighborhood of Túnel, where mollusks have been collected.

The reason for the discordant age for the Balanus is not clear, but it must be noted that the habitat of this species is quite different from the other dated species. According to the x-ray diffraction analysis of the shells, Balanus and Trophon show $100 \%$ of calcite and, consequently, a post-depositional recrystallization of the aragonite of the shells into calcite along with an exchange of carbonate are suspected. This recrystallization might render a younger age.

The obtained age for the guanaco (Lama guanicoe) bones is younger than expected. It is not easy to find an explanation in terms of contamination for this sample, because the environment in which the guanaco and sea-lion bones rested was exactly the same. Unfortunately, it is impossible to know a posteriori whether the guanaco bones dated could be more susceptible to exchange or contamination than the sea-lion bones.

Also, $\delta^{13} \mathrm{C}$ values for these bone collagens are quite different; the guanaco value reflects its typical continental vegetable diet, whereas sea lion shows a value representing its marine diet. Both $\delta^{13} \mathrm{C}$ values agree with those of Schoeninger, DeNiro and Tauber (1983). These data encourage further work on the adaptation of human cultures of the area to maritime littoral lifeways (Orquera, Piana \& Tapia, 1984; Piana, 1984) based on $\delta^{13} \mathrm{C}$ changes of human bone collagen.

\section{CONCLUSIONS}

The obtained value for the reservoir effect of $\Delta=-74 \pm 16 \%$ or $620 \pm 140 \mathrm{yr}$ is greater than those obtained by Mangerud and Gulliksen 
(1975) for Norway and Spitsbergen and smaller than those of Arctic Canada. If these values are recalculated (Olsson, 1980) the mean reservoir age for Arctic Canada $(640 \pm 160)$ is similar to that obtained at Túnel. This $\Delta$ value is smaller than those reported by Taylor and Berger (1967) for the Chilean and Peruvian coast when these are normalized to $\delta^{13} \mathrm{C}=-25 \%$. Unfortunately, the correlation of this effect with marine dynamics is impossible owing to the lack of studies on the Beagle Channel dynamics, ignoring the relative Atlantic and Pacific water masses contributions. Even if present dynamics were known, their usefulness would be poor. Isotopic data on shells found at this site show a paleotemperature evolution (Panarello, pers commun, 1985) and, consequently, a probable variation in channel dynamics occurred.

This works shows the first results of evaluation of the reservoir effect at Tierra del Fuego from the past, using archaeologic information. Additional work must be done to understand the age discordance between the Lama guanicoe and charcoal and the behavior of mollusks such as Trophon and Balanus the ages of which deviate from the other marine shells.

At several sites in the island contemporaneous marine and terrestrial datable materials are found and the special environmental conditions make charcoal a reliable reference in the evaluation of the effect as a function of time.

\section{ACKNOWLEDGMENTS}

We thank L A Orquera who helped us with the manuscript and E Linares for his support. We also thank J L Nogueira for the benzene synthesis, $\mathrm{O}$ González for his help in collagen preparation, our colleagues at the Stable Isotopes Laboratory, and the Asociación de Investigaciones Antropológicas under which the archaeologic investigation was conducted.

\section{REFERENCES}

Albero, M C and Angiolini, F E, 1983, INGEIS radiocarbon laboratory dates I: Radiocarbon, v 25, p 831-842.

Berger, R, Taylor R E and Libby, W F, 1966, Radiocarbon content of marine shells from the California and Mexican West coast: Science, v 153, p 864-866.

DeNiro, M J and Epstein, S, 1981, Influence of diet on the distribution of nitrogen isotopes in animals: Geochim et Cosmochim Acta, v 45, p 341-351.

Dick, W and Fyles, J G, 1962, Geological Survey of Canada radiocarbon dates I: Radiocarbon, v 4, p 13-26.

Fergusson, G J and Libby, W F, 1963, UCLA radiocarbon dates II: Radiocarbon, v 5, p 122.

Hubbs, C L, Bien, G S and Suess, H E, 1960, La Jolla natural radiocarbon measurements: Radiocarbon, v 2, p 197-223. 117.

Mangerud, J and Gulliksen, S, 1975, Apparent radiocarbon ages of recent marine shells from Norway, Spitsbergen and Arctic Canada: Quaternary Research, v 5, p 263-273.

Olson, E A and Broecker, W S, 1959, Lamont natural radiocarbon measurements V: Radiocarbon, $\mathrm{v} 1, \mathrm{p} 1-28$.

Olsson, I U, 1980, Content of ${ }^{14} \mathrm{C}$ in marine mammals from northern Europe, in Stuiver, $\mathrm{M}$ and Kra, R S, eds, Internatl ${ }^{14} \mathrm{C}$ conf, 10th, Proc: Radiocarbon, v 22, no. 3, p 662-675.

Orquera, L A and Piana, E L (ms), 1983, Prehistoric maritime adaptation at the MagellanFueguian littoral: Paper presented at New World Maritime adaptation symposium, 48th ann mtg, Soc Am Archaeol, Pittsburgh.

Orquera, L A, Piana, E L and Tapia, A H (ms), 1984, Evolución adaptativa humana en la 
región del Canal de Beagle: Paper presented at lst Jornada Arqueol Patagonia, Trelew, Argentina.

Panarello, H O, García, C M, Valencio, S A and Linares, E, 1981, Determinación de la composición isotópica del carbono en carbonatos. Su utilización en hidrogeología y geologia: Rev Asoc Geol Argentina, v 35, no. 4, p 460-466.

Piana, E L, 1984, Arrinconamiento o adaptación en Tierra del Fuego, in Ensayos de Antropología Argentina (1984): Buenos Aires, Univ Belgrano, p 5-110.

Säve-Söderbergh, T, $1970,{ }^{14} \mathrm{C}$ dating and archaeology, in Olsson, I U, ed, Radiocarbon variations and absolute chronology, Nobel symposium, 12th, Proc: New York, John Wiley \& Sons, p 645-649.

Schoeninger, M J, DeNiro, M J and Tauber, H, 1983, Stable nitrogen isotope ratios of bone collagen reflect marine and terrestrial components of prehistoric human diet: Science, v 220, p 1381-1383.

Stuiver, $\mathrm{M}$ and Polach, H A, 1977, Reporting of ${ }^{14} \mathrm{C}$ data: Radiocarbon, v 19, p 355-363.

Taylor, R E and Berger, R, 1967, Radiocarbon content of marine shells from the Pacific coasts of Central and South America: Science, v 158, p 1180-1182. 